\title{
Politics of Evasion and Tales of Abjection: Postmodern Demythologization in Angela Carter and Ghazaleh Alizadeh
}

\author{
Narges Montakhabi Bakhtvar \\ Central Tehran Branch, Islamic Azad University, Tehran, Iran \\ Hoda Niknezhad-Ferdos \\ Central Tehran Branch, Islamic Azad University, Tehran, Iran
}

Follow this and additional works at: https://docs.lib.purdue.edu/clcweb

C

Part of the Comparative Literature Commons, and the Feminist, Gender, and Sexuality Studies Commons

Dedicated to the dissemination of scholarly and professional information, Purdue University Press selects, develops, and distributes quality resources in several key subject areas for which its parent university is famous, including business, technology, health, veterinary medicine, and other selected disciplines in the humanities and sciences.

CLCWeb: Comparative Literature and Culture, the peer-reviewed, full-text, and open-access learned journal in the humanities and social sciences, publishes new scholarship following tenets of the discipline of comparative literature and the field of cultural studies designated as "comparative cultural studies." Publications in the journal are indexed in the Annual Bibliography of English Language and Literature (Chadwyck-Healey), the Arts and Humanities Citation Index (Thomson Reuters ISI), the Humanities Index (Wilson), Humanities International Complete (EBSCO), the International Bibliography of the Modern Language Association of America, and Scopus (Elsevier). The journal is affiliated with the Purdue University Press monograph series of Books in Comparative Cultural Studies. Contact:<clcweb@purdue.edu>

\section{Recommended Citation}

Montakhabi Bakhtvar, Narges; and Niknezhad-Ferdos, Hoda. "Politics of Evasion and Tales of Abjection: Postmodern Demythologization in Angela Carter and Ghazaleh Alizadeh." CLCWeb: Comparative Literature and Culture 22.4 (2020): <https://doi.org/10.7771/1481-4374.3367>

This text has been double-blind peer reviewed by $2+1$ experts in the field.

The above text, published by Purdue University Press @P Purdue University, has been downloaded 0 times as of 03/14/ 21.

This document has been made available through Purdue e-Pubs, a service of the Purdue University Libraries. Please contact epubs@purdue.edu for additional information.

This is an Open Access journal. This means that it uses a funding model that does not charge readers or their institutions for access. Readers may freely read, download, copy, distribute, print, search, or link to the full texts of articles. This journal is covered under the CC BY-NC-ND license. 


\section{PURDUE}

UNIVERSITY PRESS <http://www.thepress.purdue.edu>

\section{CLCWeb: Comparative Literature and Culture}

ISSN 1481-4374 <http://docs.lib.purdue.edu/clcweb> Purdue University Press (CPurdue University

CLCWeb: Comparative Literature and Culture, the peer-reviewed, full-text, and open-access learned journal in the humanities and social sciences, publishes new scholarship following tenets of the discipline of comparative literature and the field of cultural studies designated as "comparative cultural studies." In addition to the publication of articles, the journalpublishes review articles of scholarly books and publishes research material in its Library Series. Publications in the journal are indexed in the Annual Bibliography of English Language and Literature (ChadwyckHealey), the Arts and Humanities Citation Index (Thomson Reuters ISI), the Humanities Index (Wilson), Humanities International Complete (EBSCO), the International Bibliography of the Modern Language Association of America, and Scopus (Elsevier). The journal is affiliated with the Purdue University Press monograph series of Books in Comparative Cultural Studies. Contact: <clcweb@purdue.edu>

\section{Volume 22 Issue 4(December 2020) Article 11 \\ Narges Montakhabi Bakhtvar and Hoda Niknezhad-Ferdos, "Politics of Evasion and Tales of Abjection: Postmodern Demythologization in Angela Carter and Ghazaleh Alizadeh"}

<http://docs.lib.purdue.edu/clcweb/vol22/iss4/11>

Contents of CLCWeb: Comparative Literature and Culture22.4 (2020)

$<$ http://docs.lib.purdue.edu/clcweb/vol22/iss4/>

Abstract: Angela Carter and Ghazaleh Alizadeh as the prophetesses of postmodern fairy tales in British and Persian literature re-narrativize these tales as a loophole from socio-political stagnation and cultural paralysis. Evading direct contact with the political jargons of their eras, they seek gender generativity via the fairy tale machine. Alizadeh finds refuge in modernizing Persian fairy tales. Carter chants her frustration at Thatcherism through gender subversion. Carter's and Alizadeh's revulsion at the politics of gender in their eras can be read via the duet between the abject and the chora in Kristeva's thought. It is through the encounter with the external abject that the internal abject is activated culminating in the efflorescence of the chora. The liminality of the chora becomes the battleground on which poetics of gender beats off politics of logos through subversion and syncretism. While Carter obtains abjection through overt sexualization of fairy tales, Alizadeh resorts to indirection due to the political climate of her time. Unlike Carter who is quite outspoken about her fairy tale project, Alizadeh is reticent, allusive, and somber trying to remind her readers of the gloomy reality that being a woman in the Middle Eastern countries is always already punctuated with docility. 


\section{Narges Montakhabi BAKHTVAR and Hoda NIKNEZHAD-FERDOS}

\section{Politics of Evasion and Tales of Abjection: Postmodern Demythologization in Angela Carter and Ghazaleh Alizadeh}

\section{Introduction}

The nexus between recalibration of fairy tales and reconfiguration of femininity has become a manifest mark on the body of postmodern feminist writings. From an array of English and American writings in this arena, including the poetry collections of Anne Sexton in her Transformations (1971) and Olga Broumas in Beginning with O (1977), or works of fiction as in Fay Weldon's The Life and Loves of a SheDevil (1983), Jeanette Winterson's Oranges Are Not the Only Fruit (1985), Margaret Atwood's The Robber Bride (1993), Kate Atkinson's Behind the Scenes at the Museum (1995) and Human Croquet (1997), Angela Carter's The Bloody Chamber (1979) stands out with its radical and iconoclastic resexualizing of fairy tales. This particular area of contemporary literature displays cognizance of the fact that the fairy tale machine, in Laura Mulvey's words, "demands sadism, depends on making something happen, forcing a change in another person, a battle of will and strength, victory/defeat, all occurring in a linear time with a beginning and an end" (14)(See also Teresa de Lauretis' essay "Desire in Narrative"). Mulvey's proposition can be expanded for the purpose of this study; the re-narrativization and deterritorialization of fairy tales as the consistent accoutrements of feminist writings in the second half the twentieth century pertains to the fact that storytelling is always already impregnated with the ramifications of maternity, creation, birth, and above all, pain regardless of geography, demography, and cultural differences. Postmodern writers across the world who are interested in retelling fairy tales share the zest for anti-logocentrism as they try to defy cultural dogmas. Postmodern fairy tales "like meta-folklore, constitute an ideological test for previous interpretations, and in doing so, postmodern fairy tales exhibit an awareness of how the folktale, which modern humans relegate to the nursery, almost vindictively patterns our unconscious" (Bacchilega22).

This study aims to illuminate the fact that de-mythologization, or in Jack Zipes' terminology, the "antimyth" (5) of fairy tales, that is, dismantling their magic and biopsying their combination of gender, ideology, and desire forges a common language among heterogeneous cultures under the auspices of sociopolitical dicta and institutional imperatives. For Zipes, "fairy tale is myth. That is, the classical fairy tale has undergone a process of mythicization. Any fairy tale in our society, if it seeks to become natural and eternal, must become myth. Only innovative fairy tales are antimythical, resist the tide of mythicization, comment on the fairy tale as myth" (5). In this spirit, contemporary Persian literature by female writers seethes with a folkloric aura and is a carrier of transformed and transformative fairy tales which are recalibrated, mobilized, and acculturated upon the religious and sociopolitical climate of the 1979 Revolution. The cultural anxieties, moral invocations, and conservative milieu that have their origin in the Revolution can provide solid bedrock for a comparative survey of western and eastern triangulation of gender, subjectivity, and performativity. Thus, Carter's unique de-mythicization of fairy tales is to be compared with Ghazaleh Alizadeh's fiction. Alizadeh's fiction is the undeniable harbinger of postmodernism in the Iranian feminist writings of the 1970s. Alizadeh harnesses her fiction into denationalizing and post-humanizing Persian fairy tales, which absolutely contradict the commitments of the fiery and pedantic aficionados of Persian literature's antiquity and grandeur, whose concentric and monadic view has been depriving Persian literature from discursive and intercultural exchange with world literature. The fetters of classicism, didacticism, and decorum on Persian literature have led the literati inside and outside Iran to still laud the medieval poetry of Saadi (سعدى) or Rudaki (رودىى). Being the diva of postmodern fiction writing in the late twentieth century Tehran, Alizadeh's fiction radiates with powerful and enduring vectors of polyvalence, dissidence, and ethos of intersubjectivity, eschewing the sanctification of essentialism. Although standing culturally, socially, and politically apart, Carter and Alizadeh vouch for the idea that subversion of compelling gender norms summons a genealogical view; it is intimately centered on re-narrating the genesis, the beginning, and the first stories in Persian and Western cultures. As a result, a comparative outlook toward Carter and Alizadeh can unmask the enactment and and transformation in the triad of fairy tale, narrative, and gender.

There are numerous critical and scholarly writings on the implications and roles of fairy tales in western literature and their postmodern adaptations. Christina Bacchilega in Postmodern Fairy Tales: Gender and Narrative Strategies (1997) and Kevin Paul Smith in The Postmodern Fairy Tale: Folkloric Intertexts in Contemporary Fiction (2007) have delved deep into contextualization, consumption, and criticism of fairy tales in postmodern writings from different angles. Moreover, the critical and analytical investigation into western fairy tales is extensive and remarkable: Bruno Bettelheim's Freudian excursus 
in The Uses of Enchantment (1976) or Gertrude Mueller Nelson's Here All Dwell Free (1991) with its Jungian spirit.

Also, there exist numerous scholarly articles on Carter through diverse perspectives; however, comparative ones are not abundant. Among them, Anna Watz in her book Angela Carter and Surrealism: "A Feminist Libertarian Aesthetic" (2016) states that Carter employs mythology "as a lens through which the intersection between surrealism, structuralism/poststructuralism and feminism." The three key terms "coalesce to form the central mode in [her] later work" (22). Carter's fiction "is a rewriting of several myths and narratives, ranging, ... from Greek mythology" (138) to "modern myths and hidden ideologies behind them; she seeks to deconstruct 'certain configurations of imagery', which are culturally produced to appear 'natural' and timeless" (107).

Esther Maria D'Cruz in "Transmogrification Depicted in Angela Carter's The Bloody Chamber" (2016) mentions that Carter's works expresses "transformation that occurs due to absurd powerful relationships" (29). Moreover, they "focus on the ambivalent and complex characterization along with explicit sexual relationship to bring about a condition for change, a change that once gone through will have no going back" (30). She elaborates that Carter's works manifest the way "short stories aped from fairy tales can be erudite towards brings out the essence of sexuality, transformation from innocence to reality and the realm of transmogrification" (31).

Antra Leine in "Angela Carter's Version of The Little Red Riding Hood" (2014) has juxtaposed Carter's "The Company of Wolves" with Charles Perrault's "The Little Red Riding Hood" and clarified the way Carter deliberately upends the readers' expectations with an aim to disclose the concealed content of the fairy tales. She mentions that "Carter creates a rich, extraordinary, sensual tale threaded with intertextual motifs, such as male dominance in the role of sexual predators, and traditional morality requiring female chastity and submissiveness" (55). Also, Maria José Pereira Pires in Dealing with Appetites: Angela Carter's Fictions (2012) endeavors to explore Carter's fictions through an angle of gastro-criticism and emphasizes that it could be "the representations of food as a form of characterizing fictional characters" (331) who disclose the veiled aspects of humanity.

Iwona Wrobel in "Femininity and Masculinity as the Axis Magical Worlds: A Comparative Analysis of Angela Carter's and Olga Tokarczuk's Heroines" (2006) spotlights the notion of femininity and masculinity in the realm of Magical Realism: "The women in Carter's texts appear to be very sensitive, hesitant, and most of all-misunderstood by the men's world. In this world only a woman can understand a woman and agreement with a man resembles more a contract than something else, which amounts to a certain sum, and breaking it can happen at any time with the woman not being able to withdraw" (189). Illuminating the diverse world of femininity and masculinity, Wrobel lime lights the unique sphere of femininity in Carter's and Tokarczuk's heroines.

Anne Susan Koshy in her book The Short Fiction of Angela Carter, Margaret Atwood and Suniti Namjoshi (2003) compares the works of these three writers through the lens of sexual politics and argues for the therapeutic value of their extraordinary narratives. She asserts that the three abovementioned authors "of different nationalities have reworked traditional fairy tale narratives to present an alternative female paradigm by bringing omen to the center and erasing the margins" (29). She carries on that "they have also attempted to explore crucial feminist issues and to express their dissent of the dominant patriarchal regime that must inevitably change" (30). Finally, Karen Isabel Okana in her MA thesis Synthetic Authenticity: The Work of Angela Carter, Gilles Deleuze and Félix Guattari (1996) comparatively scrutinizes Carter's works with Gilles Deleuze and Félix Guattari's and asserts that they have the notion of synthetic authenticity in common, captured through the notions of "Becomings," "Events," and "Machines." She elucidates that, "Carter, Deleuze and Guattari have questioned the revolutionary power of desire per se" (76). Elucidating "becoming, "Okana represents it in Carter's fictional characters.

Due to Alizadeh's particular political and feminist standpoint, her works have not been prolifically explored. Masoumeh Zare Kohan and Azar Daneshgar in "The Analysis of Motifs in Ghazaleh Alizadeh's Short Stories" (2017) claim that her method of utilizing motifs "sheds light on Alizadeh's life and thoughts and focuses on her book titled With Ghazaleh to Nowhere. The collection and analysis of the motifs in her stories is a gateway to determine the process and pattern of her thoughts" (49). In "Intellectuals and Alienation: A Comparative Study of Ghada Al-Samman and Ghazaleh Alizadeh's Novels" (2013), Yadollah Ahmadi and Somayyah Aghajani assume a postcolonial viewpoint toward Alizadeh's The Edrisis' House and Al-Samman's Beirut Nightmares. They argue that the "origins of intellectuals' alienation - in his country and country of emigration - return to the function of social and political powers in her society" (1). Also, Farah Niyazkar in "Ideal Woman, Enchanting Woman in the Works of Simin Daneshvar, Shahrnush Parsipur, Ghazaleh Alizadeh, Moniru Ravanipor and Bilqis Solimani" (2013) demonstrates that "writing fiction by women is an important sign of social, cultural 
and human developments that occurred in Iranian women's life. Women who seek to be the voice of the various segments of the society, to express the pains, wishes and demands of their society, and show the pain imposed on them by the society due to conditions, from enchanting woman to ideal woman" (323). Taking into account the literature review, it can be claimed that the contrasting of western and Persian fairy tales in postmodern fiction has not yet been comprehensively undertaken. This research aims at filling this gap by comparatively assessing the short fiction of Carter and Alizadeh as the two pioneers in the field of postmodernizing fairy tales in British and Persian literature.

Widely accredited as one of the most significant English writers of the century, Carter's works represent her bawdiness, linguistic zest, astonishing inventiveness and assortment. Her reputation as both a cultish and canonical writer is a result of demythologization of gender by/in fairy tales as the locomotive of her surreal and postmodern narratives. In Bacchilega's words, "as an enthusiastic listener/reader of both folk and fairy tales, and as a writer who draws from many versions, oral and literary, Carter tells tales that reactivate lost traditions, trace violently contradictory genealogies, and flesh out the complex and vital workings of desire and narrative" (59). Also, Martine Hennard Dutheil argues that Carter's infatuation with fairy tales "partly stemmed from a recognition of the extraordinary potential of the genre to carry out poetic and artistic experiments, and it also reflected an awareness of its crucial social role in shaping a sense of self and understanding of the world from an early age" (204). Considering social role as one of the most significant pillars of feminine identity, Dutheil expands the concept of femininity.

Rejecting Oxford Education, Carter established her career as a journalist in Croydon Advertiser; however, she studied Medieval Literature at University of Bristol. According to Encyclopaedia Britannica, Carter "reshaped motifs from mythology, legends, and fairy tales in her books, lending them a ghastly humor and eroticism." Living in Tokyo and being immersed in Japanese culture, Carter reflected on her process of disenchantment with her Japanese lover in her work. As Imogen Pullan mentions "Fireworks is a collection of short stories where accounts of her time in Japan are weaved around fictionalized, often disturbing tales, and she also wrote nonfiction essays about the author Yukio Mishima, fertility festivals and other elements of Japanese culture." Being brought up in an eccentric atmosphere, Carter demystified the mother/child relationship and presented it as a strange phenomenon. Joan Acocella in "Angela Carter's Feminist Mythology" (2009) asserts that Carter was "the second child of a straitlaced mother, Olive who used to turn off the TV if a divorced actor came on the screen." Rebelling against her mother, Carter transformed from a reticent and reserved girl into a vulgar and discourteous one. Acocella argues further that not being allowed to dress herself, or to go to the bathroom alone, Carter ultimately "rebelled, went on a diet, and changed from a fat, obliging girl to a skinny, rude girl. She slouched around in short skirts and fishnet stockings, smoking and saying offensive things to her mother." Reflecting the political and feminist debates on pornography, Carter defends Sade for treating all sexual reality as political one. Robin Ann Sheets in "Pornography, fairy Tales and Feminism: Angela Carter's The Bloody Chamber" (1991) states that Carter "holds a problematic place in the debates about pornography that have polarized Anglo-American feminists, originally over the issue of sadomasochism and other sexual practices and more recently over the question of artistic representation" (633). Endeavoring to delve into female sexuality, Carter appears to elucidate female body as a stark manifestation of political reality.

On the other side, Alizadeh's obscurant spectacle of interanimating fairy tales shies away from the elevated, ornate, and Arabized language of classical Persian literature as it enkindles schizophrenic, fractured, and hallucinatory narratives of loss and desire. She was born in 1948 in Mashhad and began publishing her stories and a novel in the 1970s. Her most acclaimed work, however, appeared after the 1979 Revolution in the form of two novels and one collection of stories: Two Views (دو نظظره) (1984), The Idrissis' House (خان/ادربيسىها) (1992), and The Intersection (1994). According to Encyclopedia Iranica, "she was one of the signatories to the politically consequential declaration in defense of freedom of speech, issued by prominent members of Iran's intelligentsia in 1994, known as We Are Writers" (Mirabedini). Experiencing both the pre- and post-Iranian Revolution era and studying Political Sciences at University of Tehran and Sorbonne University enabled her fiction to portend polysemy and crepuscularity. Her most acclaimed novel, The Edrissis' House, was the recipient of the "Twenty Years of Fiction Writing" award of the Ministry of Islamic Culture and Guidance in 1999. Alizadeh's suicide in 1996 (hanging herself from a tree near a village in northern Iran) reveals the fact that "in her fiction, she illustrates that the situation of women has changed, that they struggle insistently, and that because they do not gain much success they become highly disappointed" (Talattof 193). Her narratives hover around younger Iranian women's lives and experiences, and they are imbued with Persian folk tales. 
Being born in a wealthy and cultured family, she benefited from an early education by her mother, Monir Sayyedi, a poet and fiction writer, and the author of Payk-eĀseā (The Known Messenger, 1998). According to Encyclopedia Iranica:

Alizadeh had an early exposure to the intellectual and literary world. Twice a month, her mother hosted a literary circle in her home. The gatherings, attended by eminent literary figures and scholars, such as Sa'id Nafisi (1895-1966), and Mehdi AkavānTāleț (1928-1990), had a lasting influence on Alizadeh's intellectual development. She read the works of great poets in every session or wrote an article about them, gradually developing a lasting interest in politics and literature. By 1967 her stories made their way to $\bar{A}$ raš, one of the reputable literary journals of the period. Among her supporters at Ārašwas JalālĀl-e Ahmad (1923-69), the prominent novelist and influential social critic, who encouraged Alizadeh's romantic rejection of urban life and industrialized society. (Mirabedini)

Mohsen Mihandust in "Now that She is not Here, I am Telling You" (2002) asserts that "Formative influences on Alizadeh's intellectual development and her hybrid literary canon derived from the Persian literature and mysticism, to which she had been exposed from an early age, on the one hand, and the French literary tradition, on the other. Among her favorite French novelists was Gustave Flaubert whom she believed to be influenced by Eastern mystical thought and whose extraordinary vigor and exactitude of expression she strove to emulate in her own work" (545). One of the significant traumas she experienced was the confiscation of her parental home, which made the city, home, and memories of childhood appear as recurrent motifs in her stories. In "The Pain of Immortality" (1990), Jalal Sattari states that Alizadeh's kāna-ye Edrisihā (The Edrisis' House) in which "love, dream, and mystical alchemy govern, is the tale of a house confiscated by the revolutionary authorities, and handed over to new residents, who are caught in a metaphorical clash between a decadent culture and a defiant emerging one" (138). Her postmodern short stories "The Twin" (جقت) (first published in Arash 16, 1967) which sets in motion a plethora of significations such as "couple," "twin," and "placenta" in Persian language, and "The Pure Tree" (شجرة طييه) (first published in The Impassible Journey in 1977, a collection of Alizadeh's three stories complied by Omid Rouhani) are selected to be studied in terms of their reciprocities with Carter' "The Snow Child" and "The Werewolf." Alizadeh's stories surrealistically envision liminal spheres in which the characters experience psychosis and disequilibrium via excavating Iranian fairy tales and re-echoing them in new-fangled modern contexts.

With the abovementioned background to Alizadeh and Carter, it can be speculated that both of them explore fairy tale narrative by dislodging established cultural conventions and cultivating innovative discourse on gender, femininity, and desire. In this regard, their many postmodernized fairy tales can be tackled by the means of political evasion. Wracked by the socio-political climate of the 1980s, Carter castigated the restrictions and denominations of political genres: "She voted Labor and loathed Margaret Thatcher, but when she attended a meeting of leftwing writers and intellectuals in 1988, she felt badly out of place, and barely said a word. She refused identification with any movement, and resisted attempts to absorb her work into any genre" (Gordon55). In a similar vein, Alizadeh's perspective on the political climate before and after the Revolution led her increasingly toward isolation as she felt disillusioned with both the pre-Revolution mottos of "Independence" and "Freedom" from the West, and post-Revolution anxieties. Being fettered by the new social mandates, Alizadeh was obliged to revert to indirection in her narrations when it came to thorny issues of femininity, sexuality, and power. That is antithetical to Carter's explicit representation of sex, violence, and eroticism. Moreover, while Carter's oeuvre was highly visible and expounded in different literary circles, Alizadeh remained mostly unknown and her works were received unenthusiastically. Aydin Aghdashloo, the prominent contemporary Iranian painter, in The Years of Fire and Snow laments that "I was confident, yet in vain, that when a diva of such a great significance passes away, scholars would declaim her literary superiority; however, there were merely two articles on her, one insufficient and the other tawdry" (87). It could be asserted that ignoring Alizadeh's suicide could be interpreted as eradicating even the non-presence of the female voice.

Political evasion in Alizadeh and Carter also betokens the yawning conservatism of their eras. The post-revolutionary Iran was solidified into a state that domesticated and immobilized women despite their active participation during the uprising by joining the rallies, fighting as armed guerillas, resisting sexualization and commodification of women in the Pahlavi cinema and media. Nonetheless, the demands for liberation and liberalism were thwarted with political and social inertia. Whether Islamist or feminist, the anti-monarchical context was a fertile ground for women's liberation movement in Iran that was yet to come to full fruition. Similarly, Carter was raged at the failure of the Labor Government in the 1970 s due to its inability to terminate economic crisis and unemployment. Also, Thatcher's conservative policies and her indifference to women's movements in Britain were repudiated by Carter 
as she reoriented her literary path, disavowed political activism, and ventured into the fairy tale enterprise. For her and many other reformists, Thatcher became, as Natasha Walter puts it, "the antifeminist icon" who was "reactionary," caring "little for equality of any sort and who a contemptuous indifference to the arts" regarded "as a man dressed up in a skirt suit. Or a woman who used the traditional weapons of sex and flirting to get what and where she wanted."

Considering Kristeva's concepts of abjection and the semiotic chora, the core idea to be explored in this study is the dual exchange between the abject and fairy tales as Carter and Alizadeh consign the magical to critical moment(s) of abjection and concomitant semiotic processuality. The formation of subjectivity and desire in Carter and Alizadeh is related to demythologization of fairy tales and demystification of femininity in tandem with the resurgence of the abject. By crossing the border between the witch and the fairy, the demon and the angel, the human and the animal, Carter's and Alizadeh's stories reach the crescendo of gender liminality and aporia hallmarked in Kristeva's thought.

First it is instructive to look at Kristeva's views on abjection and the chora. Abjection, which denotes the condition of being castoff, is transformed in Kristeva's thought as she bespeaks of a new terminology for the discourse of "other." In Powers of Horror, she posits that "the abject is not an ob-ject facing me, which I name or imagine. Nor is it an ob-jest, an otherness ceaselessly fleeing in a systematic quest of desire. What is abject is not my correlative, which, providing me with someone or something else as support, would allow me to be more or less detached and autonomous. The abject has only one quality of the object - that of being opposed to I" (1). In Kristeva's ethos of otherness, abject is the medio (in Giorgio Agamben's sense of the word) between subject and object: "The abject has only one quality of the object-that of being opposed to I. If the object, however, through its opposition, settles me within the fragile texture of a desire for meaning, which, as a matter of fact, makes me ceaselessly and infinitely homologous to it, what is abject, on the contrary, the jettisoned object, is radically excluded and draws me toward the place where meaning collapses" (Powers 2). Kristeva's conceptualization of the abject as the objected subject takes a new turn by becoming fraught with bedlam and repulsion. Exemplifying the abject, she brings forth the case of nausea as, for her, food is not the "other" for "me"; "I expel myself, I spit myself out, I abject myself within the same motion through which I claim to establish myself" (3). As Elizabeth Gross in "Abject Bodies" elaborates, "Kristeva explores the ways in which the inside and the outside of the body, the spaces between the subject and object and the self and other become structured" (86). Kristeva's speculations are conducive to the idea that encountering the abject outside unleashes the abject inside.

The second decisive term in Kristeva's semiotic-feminist palette is the chora. Reminiscent of Plato's postulations in Timaeus, chorais the articulation of kaleidoscopic significations including nourishing maternal space, uterus, and the Lacanian Imaginary. In her essay "Motherhood According to Giovanni Bellini" from Desire in Language (1980), Kristeva foregrounds the chora as a "non-expressive totality formed by drives and their stases in a motility that is full of movement as it is regulated" (25). She carries on the argument and asserts that it is the mother's body that evinces equidistance between the chora and the symbolic realm. This means that the mother catalyzes nature and culture, signification and semiosis. Separation from the mother as the traumatic aftermath of the Symbolic Order, in Kristeva's view, is synonymous with abjection; it is repulsive, pernicious, yet transformative. The unending fluctuation between the semiotic and the symbolic, hence, exposes subjectivity to the maelstrom of processuality and contingency.

\section{The Ejection of Exorbitant Inside: Flux of Abjection in Carter and Alizadeh}

The juxtaposition of Carter's "The Snow Child" and "The Werewolf" with Alizadeh's "The Twin" and "The Pure Tree" within a Kristevan frame can capture dichotomous cultural dogmas and dictates attached to the abject in fairy tales. Due to the revolting aspect of the abject, its brutal and murky insurrections are targeted in Carter's and Alizadeh's feminine cosmology and their politics of evasion. That is to say, the abject is commensurate with their biaxial attitude towards politics; on the one hand, Carter and Alizadeh discredit the faltering progress of political creeds and show their denunciation by the use of fairy tales. On the other hand, the encapsulation of the abject in their texts can be hailed as political if abjection is deemed as a new political gestalt in which subversion is thematized.

Carter's "The Snow White" has garnered various interpretations, ranging from a "successful resolution of the Oedipal conflict" (Bruno Bettelheim), "female rite of passage" (N. J. Girardot), the binary of the "angel-woman" and the "monster-woman" (Sandra Gilbert and Susan Gubar), to "a mother who cannot grow up and a daughter who must" (Bacchilega31). Being an adaption from a barely known fairy tale published by Bolte and Polivka in the early twentieth century, the story undermines "mythic versions of women" (Carter, The Sadeian 5). Carter's rendition of this fairy tale is set in the dead of winter as the Count and the Countess ride their horses through the freshly-fallen snow. Encountering a 
blood-filled hole and a raven, the Count desires to have a girl and instantly a girl appears; as white as the snow with blood-red lips and raven-black hair. The envious Countess attempts to get rid of her and despite her wicked manipulations, the girl keeps on riding along with them. But she is killed when her finger is pricked by a thorny rose. The Count rapes the girl's corpse in the Countess's presence and subsequently, her cadaver melts away leaving behind a raven feather and a bloodstain on the snow. Eventually, the Countess is pricked by the rose when the Count brings it to her.

The Snow Child's abject, uncanny, and aporetic existence that seesaws between being and nonbeing, human and nonhuman, angel and demon is a result of her appearance in the narrative as the object of the Count's eros and the subject of the Countess's desire. After her genesis, the Snow Child starts controlling the Countess vicariously through the Count. Hence, the fairy tale and classic leitmotif of mother/daughter rivalry are conjoined as both the object and subject of desire are materialized in the Snow Child. The Countess in "high, black, shining boots with scarlet heels and spurs" (Carter, The Bloody 110) drops her glove and orders the child to pick it up. However, the Countess's power game fails when the Count announces: "I'll buy you new gloves." At this very moment, "the furs sprang off the Countess's shoulders and twined round the naked girl." The power struggle initiated by the Countess and thwarted by the Count culminates in her abandonment. The Snow Child's transformation into the fading inbetween corpse-blood-feather is a manifestation of Kristeva's abject, as Carter herself puts it, "to be the object of desire is to be defined in the passive case. To exist in the passive case is to die in the passive case - that is, to be killed. This is the moral of the fairy tale about the perfect woman" (The Sadeian 76-7). In oscillating between passivity and non-passivity, it could be argued that femininity belongs to the realm of aporetic abjection.

The Snow Child's transversality and her mobility inextricably linked with the natural (snow and rose), the animal (feather), and the organic (bloodstain), which are sutured into the semiotic rhizomatics of abjection through which the object is subjectified and the other way around. For that matter, upon being metamorphosed into the rose, the Snow Child "bites" the Countess's hand. The reverse subjectification of the object reflected in the rose's liminality as both the human and nonhuman paints with vivid strokes another instance of abjection in the narrative. The Snow Child's abjection emancipates her from the gender percepts imposed by the Count and the Countess; the abject cannot be possessed, named, and compartmentalized. So it can be concluded that Carter is not merely recapitulating the "struggle to survive at other woman's expense" (Bacchilega 38); her Snow Child is a Frankenstein's monster of gender and identity that forces the readers to face an territory in which sexuality cannot be pinned down or petrified.

The ominous voice in "The Werewolf" narrates the story of superstitious villagers who hunt witches and stone them to death. One of the villagers, a little girl, on her way to her grandmother's house, comes across a wolf and maims it by cutting off its paw and wrapping it in a piece of cloth. Having arrived at her grandmother's house, she finds her feverish, lying on the bed with a severe wound on her hand. The wrapped paw transforms into the grandmother's hand as the villagers declare it a witch's hand because of what they call a "witch wart" on it. They stone the ailing grandmother to death and the little girl "prospers" in her house. From among "women-in-the-company-of-the-wolves" (Bacchilega59) narratives of Carter, "The Werewolf" has served as critics' desideratum for its vast historical, social, and mythological references. In this story, Carter weaves together a colorful tapestry of Scottish and French folk tales, "seventeenth- century British plays" (Summers228), and various adaptations of Little Red Riding Hood. The mother's detached go-and-visit-grandmother order is completely in line with the cold, medieval, and rustic milieu of the story.

In Carter's text, ghastliness is materialized in the haunting image of the Devil, graves, corpses, the witch's supernumerary nipple, her teat, and paw-hand. The Devil is "as real as you or I" and he is "glimpse[d] often in the graveyards, those bleak and touching townships of the dead where the graves are marked with portraits of the deceased in the naif style" (Carter, The Bloody 131). Abjection is palpably illustrated once more in the silhouette of the devouring-corpse-Devil: "They dig up fresh corpses, and eat them. Anyone will tell you that" (131). The witch "whose black cat, oh, sinister! Follows her about all the time" to search for "the supernumerary nipple" (131) and the transformed paw, "no longer a wolf's paw," but "a hand chopped off the wrist" (132) pulverize the agenda of the Little Red Riding Hood fairy tale with the abject in the narrative and the narrative of the abject. Standing vis-àvis the abject, or in Kristeva's words, "the jettisoned object" (Powers 2), the subject collapses. The abject in the text unlocks hauntology; the constant return of the repressed, the surreptitious avenir of the libidinal and the violent, crowning Carter as the conjurer of the arrivant. The Count in "The Snow Child" rapes the girl's abjected corpse and the girl in "The Werewolf" stones her own grandmother to death in the presence of the abjected paw-hand. These brutish acts and their apparent ineluctability become endurable and acceptable as Carter incorporates them into her desire machine by making them 
the objets petits à of the rest of the characters. That is why the Count rapes the girl while he is aware of the fact that the Countess desires her as well. In Powers of Horror, Kristeva asserts that "we endure the viciousness of the acts since I endure it, for I imagine that such is the desire of the other. A massive and sudden emergence of uncanniness, which, familiar as it might have been in an opaque and forgotten life, now harries me as radically separate, loathsome" (2). The economy of desire forces the subjects to forcibly and formidably annihilate the abject under the rubric of regimented ideologies and taxonomies such as scapegoat-ism, purgation, and salvation. However, the abject prods the subjects into bearing out their most hideous desires, while they are conscious of the concomitant violence they commit; they are, thus, inescapably haunted from within. As Kristeva says, the abject "turns me inside out, guts sprawling; it is thus that they see that ' $\mathrm{I}$ ' am in the process of becoming an other at the expense of my own death" (Powers 2).

Alizadeh's "The Twin" depicts two insane brothers, Hamed (حامد) and Mahmoud (محمود), and their schoolteacher sister, Nayyer (نير). The story starts abruptly as Mahmoud, standing on a stool, is giving a speech in their empty room, while Hamed is playing the audience. But they are silenced and scolded by Nayyer upon her arrival. By nightfall, they all decide to go for a walk in the snowy streets. As the insane twins are playing a rolling-in-the-snow game, they start a fight and Hamed brutally kills Mahmoud. When she sees her brother's smashed and bloody corpse, Nayyer experiences a tremendous shock and starts seeing demonic creatures devouring her brother's corpse. Nayyer holds Hamed's hand, happily declaring that she is the twin from now on.

"The Twin" is the revision of a Lak (لى) fairy tale originated in Lorestan (لرستان) Province in the West of Iran. This story has appeared in the corpus of Persian fairy tales under the titles of "Sandar and Mandar" (سندر و مندر), "Vice and Virtue" (خير و شر), and "Two Brothers" (دو برادر). The original fairy tale is about two brothers, one wise and the other mad. The mad brother always follows the footsteps of his brother; jeopardizing his brother's reputation in any job (for example being a shepherd) he takes. Finally, the wise brother decides to leave the mad one behind and prosper. On his way, at night, he reaches a deserted mill and eavesdrops on the conversation among jungle animals; a fox, a porcupine, a lion, a hyena, and a panther. Each animal gives the two a task, promising the person who fulfils them would become rich and marry the king's daughter. The wise brother accomplishes all the tasks and lives happily ever after. However, the insane brother, trying to imitate the wise brother, is devoured by the animals (Heidari 33-5).

Alizadeh's "The Twin" is redolent of the mytheme of "dioscurism taken from the Greek name Dioskouroi, which means 'children of Zeus' or 'Children of the Sky' which is applied to the divine twins known as Kastor and Polydeukes in Greek Myth and ritual" (Davidson142). The twins' relationship is appears in various forms: "one twin tends to be aggressive and dynamic while the other is passive and static. For example, the Roman Castor was characterized as warlike, rash, and hot-tempered, preoccupied with going afield to fight, while his twin brother Pollux was peaceful and docile, disposed to staying at home and minding domestic affairs" (Ibid). In The Book of Kings (شاهنامه), the colossal Persian epic poetry originating inthe early eleventh century, there are multiple examples of twins like Bahman and Esfandiyār (بهمن اسفنديار), Rostam and Shaghad (رسنتم شغاد), not necessarily shaped "around the concept of brotherhood, but shadow, mirror, or mask" (Heidari, "An Analysis" 30). Otto Rank in "The Double as Immortal Self," sheds light on the concept of double. Rank postulates that "man's need for selfperpetuation, ... led to the development of civilization and its spiritual values. The primitive concept of the soul as a duality (the person and his shadow) appears in modem man in the motif of the double, assuring him, on the one hand, of immortality and, on the other hand, threateningly announcing his death" (xvi). Being the "earliest manifestation of 'Double-soul," twinship rides on "man's eternal conflict with himself and others, the struggle between his need for likeness and his desire for difference" (99). Furthermore, twinship is on a par with civilization and advancement as the wise brother's life and adventures turn on the axis of historical dialecticism and progression. Also, the twin brother fairy tale gyrates between the desire for safety of home and exoticism of the outside world: "From the earliest version on, the stories stress that both desires reside in each of us, and that we cannot survive deprived of either: the wish to stay tied to the past, and the urge to reach out to a new future" (Bettelheim 126).

Alizadeh's modification of the Persian fairy tale starts from the vantage point of inserting a mother figure, Nayyer, into the text. A curious point regarding the myth of the double in the original fairy tale is the stark absence of women in the univocal world of twinship and brotherhood. Talking animals and supernatural creatures abound, but women are absent from the process of the doubles' individuation. Also, in Bettelheim's view, "tragedy occurs if the two brothers - i.e., the two divergent aspects of our personality - do not become integrated" (131). In his view, the two brothers' story "stand for inner psychic processes which must all be functioning together for us to exist" (132). This means that psychological equilibrium requires integration and unity; generalization rather than categorization. 
Nonetheless, Nayyer's presence in Alizadeh's story disrupts the clichéd movement of the fairy tale from rags to riches, pain to pleasure, and barbarity to civilization. Nayyer, the all-caring mother/teacher, becomes the witch, $\mathrm{h}(\mathrm{a})$ unting her brothers and disturbing the unison between the two. In the Persian fairy tale, the death of one brother secures the other's prosperity, establishment of kingdom, civilization, and history; death of one brother guarantees the other's survival harking back to the ancient rituals of human sacrifice. However, in Alizadeh's story, the fratricide does not secure survival; it conjures up the abject mother, the Pandora box of trauma, loss and degeneration.

Mahmoud's corpse and his smashed head on the snow, and the hallucinatory "Tarantulas" and "Moutsvits" are the offspring of Nayyer's abject apparatus. Abjection intensifies as Nayyer starts seeing half mythological and half demonic creatures, and Tarantulas, which are half human half wolf, licking Mahmoud's blood. In Nayyer's parlance, Moutsvits are enormous black birds with flaming eyes speaking like human beings. The presence of talking animals in the original Persian fairy tale as the embodiment of a loophole from human misery and impotency is substituted by the heinous, grotesque creatures pertaining to Alizadeh's critique of logos, words, and wisdom in the classical literature of Iran. Talking animals as a recurring motif in Persian fables and fairy tales contribute greatly to the rich texture of the molecular and the nomadic in Alizadeh's fiction. Nayyer keeps on playing in the snow of the dead-end alley and takes pleasure in shouting inside a cistern as Hamed joyously imitates her. With recourse to the title of the story which signifies both "the placenta" and "the twin" in Persian, it could be stated that Nayyer desires Mahmoud's death in order to give life to Hamed, because standing in the vortex of abjection forces her to walk the tight rope over her hidden incestuous desire.

"The Pure Tree" narrates the dream-like story of a curtain purchased by Lamia (لميا) from a mysterious old salesman in the Sunday Bazaar. According to the salesman, she is destined to possess this seven or seventy or seven hundred-year-old curtain. By staring at the image of the magical tree on the curtain, Lamia's husband experiences a purgatory-like sensation and rushes to the Bazaar. Expecting the husband, the old salesman gives him the map of Acadia where the pure tree grows. Lamia's husband finds the city and the tree and never comes back. Lamia sets the curtain on fire, but keeps the ashes.

Alizadeh in "The Pure Tree" retells the obscure fairy tale of "the Girl and the Konaar Tree (Ziziphus)" (دنتر و درخت كنار), originated in Evaz (اواز), a region in Fars Province (فارس) (South of Iran). The story of the girl and Ziziphus can also be found with variation in some parts of Europe, Asia and Africa (Anderson61). Here is the story: once upon a time, there was a sterile woman yearning for a child. One day she went to the riverside with other villagers to fetch water. She saw Ziziphus and made an oath to the tree: If I have a daughter one day, you can marry her. After a while, she gave birth to a girl. The tree spoke to the girl about the oath when she became a teenage. The mother had no choice but to submit her daughter to the tree. Upon the nightfall, the trunk opened up and a voice asked the girl to enter the tree. Inside the tree, she faced a handsome young boy, Shah Nil, whose folks were all Galazangi or cannibal ogres. He was the only one in his family who was not a Galazangi. That is why he had been living alone and apart from them. Shah Nil asked the girl to keep his secret life and hiding place. But the girl could not keep the secret and Shah Nil left her. Wandering around in search of her husband, the girl accomplishes tasks and hides from her cannibal in-laws in order to be forgiven and purged (Vatanpour and Namiranian169-172).

The fairy tale possesses the following mythological morphology and motifs: "Supernatural husband, marriage, taboos, quest, and reconciliation" (Hasse 106). Shah Nil is a magician, an invisible superman who is capable of turning his wife into a vase (in order to hide her). Also, the hollow trunk of Ziziphus chimes with the Hittite rituals in which "a hollow trunk was filled with harvest offerings" (Jordan 309) to gods, particularly, Telepinu, the god of reproduction and farming. Moreover, Persian mythology (both in pre-Islamic and Islamic eras) strongly relates trees to fertility. Palm tree, as a symbol of fertility carved on coins, seals, and pottery work in the Islamic era, heralds holiness as shrines were built near trees that people thought were sacred.

Alizadeh's "The Pure Tree" begins with the surreal, blurry depiction of an unnamed city in modern Iran as the narrator's "bus number 119" arrives at "the square" (11). Alizadeh depicts the dream or nightmare of the city in a cold rainy day with images of the "subway" and "emperor's tomb." The narrator meets Lamia "in a loose khaki attire with small and formless hands that would collapse like two corpses when withdrawn" (12). Lamia's life story resembles that any other newly-married couple: in love and full of zest. Her husband would stay by the newly-born baby's crib and kiss her fingertips one by one. But once in a while, he would get gloomy and stare out of the window in rainy days, feeling crushed by the room.

Lamia starts thinking of buying a curtain and this is precisely the moment her life falls apart. In the Sunday Bazaar, in search of a good bargain, she finds an old man with wire eyeglasses and sitting motionless on a stool. He says with a smile: "I was waiting for you" (13). Out of a big wooden box filled 
with old fabrics and curtains, he draws out a strange and magnificent curtain with the image of a tree covered with red shining fruits, looking as if they are bloody. Lamia is completely overwhelmed at the sight and the salesman offers her a glass of yellow water. After drinking the disgusting liquid, she feels that the world has changed and she is not afraid of anything-even the hidden catastrophe in/of the curtain. Lamia's embracing of the abject tree is manifest in her tranquility and poise. As she hangs the curtain, everything in the room changes under the dazzling light shining from the fruits; she even stretches her hand to pick one.

Lamia has hard times describing her husband's rendezvous with the abject:

As he entered, an alien and lasting light was shining on him. He was confused, not knowing the source of light. He turned his head and saw the curtain; ... On his all perspiring body, sweat and dirt would get entangled with his hair. ... He kneels down trembling and listens to an unknown sound. It was impossible to decipher the sound; the curtain was shining with the smoothest color, as if it was the remainder of the birth of the first human child. Each fresh fruit was shaking in the breeze of wintersweet; it was the breath of dotage or pulse of being seventy years old. Each fruit was seven years old. Filled with light and blood, filled with magic. ... My husband changed completely that night. ... He said: "I have to go under the rain, it washes me, rescues me." ... He passed the most unknown alleys and deserted rivers and useless boats ... like a saint. (15-16)

Alizadeh's story and the original Persian fairy tale both include a similar roster of signs and motifs. The girl in the fairy tale is doomed to wander in exile in quest of Shah Nil. Living inside the phallic tree, the exodus, and then, accomplishing hard tasks are all requirements for developing an orthodox femininity that abides by patriarchal percepts. However, in Alizadeh, the archetypal tree gives its place to a mesmerizing image, a simulation that drags Lamia's husband into self-induced exile to Acadia and denounces his masculinity. The abject, in this case, sternly lambasts figuration of masculinity and fatherhood.

It can be inferred that Carter and Alizadeh vouch for a radical process of un-naturalizing, artificializing, and demythologizing fairy tales in order to achieve unique narratives of desire and gender. In their stories, the characters experience a dual encounter with the abject; outside and inside the self. Stumbling upon the abject enables them to recognize their interior abject-self and interconnect the external with the internal one. Such a path of subjectification resonates with Carter's and Alizadeh's withdrawal from overt feminism toward politicization of gender in terms of abjection. The Count raping the Snow Child, the mock Red Riding Hood mutilating her grandmother, Hamed slaying Mahmoud, and Lamia facing/burning the curtain-paramour all instantiate the eruption of the internal abject after facing the external one. However, in Alizadeh, the abject is beckoned by personalizing and modernizing the Persian fairy tales, while Carter's stories strictly follow the fairy tale layout and module. Unlike Carter who is quite outspoken about her fairy tale project by selecting titles and names which are reminiscent of the original stories, Alizadeh is reticent, allusive, and somber, trying to remind her readers of the gloomy reality that being an Eastern woman in is always already punctuated with docility, poise, silence, and indirection. If Carter stands on the side of eroticism, pornography, and anarchism, Alizadeh feels paralyzed halfway between affirmation and subversion as she struggles to defy the lack of the marvelous in the contemporary literature of Iran.

\section{The Logic of Exclusion and Participation: The Interval of the Chora}

The chora is the outcome of subject's encountering the outer abject and home-coming to the inner abject. In Carter's "The Snow Child," first and foremost, the abrupt appearance of the girl after the Count's desire releases the semiotic pulses of the chora. The girl triggers diverse and paradoxical feelings in the Count. In the first place, he takes the supportive role of a father against the Countess's jealousy and wickedness; however, upon her death, the Count rapes her while the Countess mourns her. Necrophilia is the semiotic crescendo in the text as the Count overcomes prescriptive gender and sexuality.

In "The Werewolf," the amalgamation of love/hatred toward the witch-wolf grandmother gives rise to the realm of disordered and chaotic sentiments in the girl's consciousness. Bracing the abject pawhand, the girl finds herself in spatio-temporal semiotic interval (metaphorized in the grandmother's house) in which all the symbols of the symbolic are defaced: "Now the child lived in her grandmother's house; she prospered" (133). In spite of the fact that the girl was armed with her father's hunting knife, she does not utilize it to slaughter her grandmother; that is to say, the symbolic is unable to totally terminate the semiotic.

In Alizadeh's "The Twin," experiencing psychosis reverberates with the maternal and semiotic cadences. After the liaison with the abject (her brother's corpse), Nayyer embraces the chora by expressing paradoxical feelings of love and hatred toward her murderer brother. Having stymied the 
symbolic, Nayyer initiates the liberating process of pre-signification as she starts hooting rather than verbalizing and no longer directs or guides her crazy brother. Kristeva in Revolution in Poetic Language asserts that "although the chora can be designated and regulated, it can never be definitively posited. As a result, one can situate the chora and, if necessary, lend it a topology, but one can never give it axiomatic form" (26). To put it into plain words, Nayyer enters a realm in which language fades away and contradictory feelings are welcomed.

In "The Pure Tree," after being exposed to the mysterious curtain, Lamia's husband frantically roams about the streets to reach the Sunday Bazaar. Accompanied by Lamia all through the quest for the holy abject, the husband meets the old salesman who is apparently waiting for him. He gives them the map of Acadia (آكاديا), on which "Ghaem Alley" (كوجهُ قائر) and house of a woman named "Saleemeh" (سليمه) are marked. In the records on the history of the Atlantic, "Arcadia [is] the name Verrazzano gave to Maryland or Virginia on account of the beauty of the trees" (Codignola4). Acadia in Alizadeh's story semiotizes the mother's womb to which Lamia's husband returns. In a letter to Lamia, he describes Acadia as a floating heaven of jungles and meadows, an unearthly maternal haven that can never be expressed through words. Ghaem, the alley in which the tree is to be found, signifies two meanings according to Amid Persian Dictionary: "stable and hidden" (1866). Also, Saleemeh, the female form of the word Saleem, has multiple denotations such as "impeccable, obedient, calm, fled from hazard, naïve and easy" (Amid1355). Lamia's husband's taking refuge in the mythic and maternal Acadia echoes the chora, in connoting solace and hazard, exposure and obscurity. Having finally arrived at Saleemeh's house and seeing the tree, he collapses with a breathtaking shiver on his body. The tree is covered with magical fruits, full of light and blood, seemingly melted, yet frozen and crystallized.

In this regard, the way Carter and Alizadeh approach the chora differs. Kevin Paul Smith in his The Postmodern Fairy Tales, suggests "eight identifiable ways in which the fairytale can operate as an intertext within mass-produced fictions":

1. Authorised: Explicit reference to a fairytale in the title

2. Writerly: Implicit reference to a fairytale in title

3. Incorporation: Explicit reference to a fairytale within the text

4. Allusion: Implicit reference to a fairytale within the text

5. Re-vision: Putting a new spin on an old tale

6. Fabulation: Crafting an original fairytale

7. Metafictional: Discussion of fairytales

8. Architextual/Chronotopic: Fairytale setting/environment. (10)

Smith believes that "the use of the fairytale title as the title of the [text], allows the reader to generate a reading of the text that appears uncontentious and even common sense. It also allows a degree of ambivalence" (13). In rapport with intertextuality and its multiple manifestations in postmodern fiction, Smith's categorization can flesh out the similarities and contrasts in Carter's and Alizadeh's attitude toward fairy tale revision. Carter's "The Snow Child" and "The Werewolf" belong to the group of "authorized" fairy tales that incorporate and re-narrate the original stories with a metafictional outlook. Carter's feminist zest for rewriting the cultural structures of identity finds its way in metafictionality of her fairy tales; assessing the coming-into-being of fairy tales can readjust the cultural and political imperatives. Fairy tales are always already metafictions testifying to their own narrativity and formation. Carter's foray into the chora, thus, is accompanied by a vivid and avid play with fairy tales and their metafictionality as she ponders upon the arche, the zero zone, the beginning of gender norms in order to reconfigure their telos. The chora storms in her texts as she stubbornly weaves it together with deconstruction and "de-creation" (in Walter Benjamin's sense of the word) of fairy tales. The chora with its constant incisions into the fortress of the symbolic, the essential, and the immanent harmonizes with Carter's tunes of contingency and haecceity orchestrated in her authority and authorship upon the fairy tales.

However, Alizadeh's repatriation to Persian fairy tales is "writerly," with vague and slippery "allusions" located in "architextual/chronotopic" settings. Her allusive and evasive disposition toward the fairy tales emanates from the doctrinal and social snares of her society. The semiotic impulses in her texts are surreptitious, uncanny, and arabesque compared to Carter's. In "The Twin" and "The Pure Tree" the fairy tale serves as the clandestine subtext underpinning the narrative. The point is that Alizadeh's covert cultivation of the abject (dead brother and the tree) is resolutely centered on the franchise of everyday life of two female characters, Nayyer and Lamia. The strict fairy tale codes of setting and narration in Carter are replaced by the sporadic and blurry images of the pure tree and the mysterious impressionistic murder of Mahmoud in Alizadeh, asseverating the fact that for Alizadeh, a Persian postmodernist, the abject should be baptized as an everyday event; it is constant, yet inconspicuous 
when it comes to a Middle Eastern woman. Nayyer's return to home after a hard day at school or Lamia's visit to the Sunday Bazaar as a daily routine congeal into an independent narrative line to which the original fairy tales become subservient. Alizadeh's female characters abjectify their everyday life in order to revolutionize the most domesticated and subdued moments of their lives. Thus, Alizadeh is the master of depicting ordinary women as archetypes; she shows the fairy tale within everyday tales. Her characters are modern, yet archaic, women who have become goddesses because of pain and suffering. They are empyrean, unreachable dream women and women of dream.

\section{Conclusion}

Carter and Alizadeh find fairy tale revision as a powerful tool for escaping the lingering and suffocating conservatism of their eras. Facing the abject and venturing into the chora serves as the two authors' anchor for performatizing gender and identity. The conservatism of late 1970s Britain and postrevolutionary Iran provide impetus for Carter and Alizadeh to explore the nature of femininity in relation and reaction to the politics of their eras. Rewriting fairy tales involves dealing with an inherent dualism: on the one hand, it reflects the reign of conservatism and passivity in contemporary politics to the extent that fabricating new narratives must reach an impasse, leaving the artist with remnants of classicism and tradition. On the other hand, re-narrating the old narratives can be deemed as radical and reformist due the contact it can afford with liminality and contingency. Carter and Alizadeh do not address contemporary issues such as women's rights or freedom; however, their politics of evasion in itself turns out to be founded on semiotics of abjection and chora that releases fluidity and processuality in their characters. By rejecting the defined roles of being a father in "The Snow Child,"grand-daughter/parent in "The Werewolf," sister/brother in "The Twin," and husband/wife in "The Pure Tree," the main characters defy ideological and ethical enchainment. Both Alizadeh and Cater are concerned with young female adulthood and the processes through which social codes and norms shape individuation, codes that are historical and mythical, real and imagined. For that matter, in order to resist the myth, they create myths; to defeat fairy tales, they retell fairy tales. For Carter, telling new stories is impossible, and for Alizadeh, new stories can be told within archetypes and folk tales.

\section{Works cited}

Acocella, Joan. "Angela Carter's Feminist Mythology." The New Yorker, 13 March 2017, https://www.newyorker.com/magazine/2017/03/13/angela-carters-feminist-mythology. Accessed 17 February 2018.

Ahmadi, Yaddollah and Somayyah Aghajani. "Intellectuals and Alienation: A Comparative Study of Ghada alSamman's and Ghazaleh Alizadeh's Novels." Quarterly of Arabic Literature, vol.5, no.1,2013, pp 1-18.

Alizadeh, Ghazaleh. "The Twin." Parceh,2012, http://www.parceh.com. Accessed 17 February 2018.

Amid, Hassan. Amid Dictionary. Amir Kabir Publishing, 2013.

Anderson, Graham. Fairy Tale in the Ancient World. Routledge, 2000.

Bacchilega, Cristina. Postmodern Fairy Tales: Gender and Narrative Strategies. U of Pennsylvania P, 1997.

Bettelheim, Bruno. The Uses of Enchantment. Thames and Hudson, 1976.

Carter, Angela. The Bloody Chamber. Penguin Books, 1993.

---. The Sadeian Woman and the Ideology of Pornography. Pantheon Books, 1978.

Codignola, Luca. "Another Look at Verrazzano's Voyage, 1524." Acadiensis, no. 39,1999, p. 4.

Davisdon, Olga M. Poet and Hero in the Persian Book of Kings. Cornell UP, 1994.

De Lauretis, Teresa. "Desire in Narrative." Excerpted in Critical Visions in Film Theory, edited by Timothy Corrigan and Patricia White with Meta Mazaj, Bedford/St. Martin's, 2011, pp. 575-593.

D'Cruz, Esther Maria. "Transmogrification Depicted in Angela Carter's The Bloody Chamber." International Journal of English Language, Literature and Translation Studies, vol. 3, no.2, 2016, pp. 29-33.

Dutheil, Martine Hennard. "Updating the Politics of Experience: Angela Carter's Translation of Charles Perrault's 'Le Petit Chaperon rouge."' Palimpsestes, no. 22, 2009, p. 204.

Farman, Bahman and Aydin Aghdashloo. The Years of Fire and Snow: Selected Words and Dialogues 1992-1999. Atiyeh, 1999.

Gross, Elizabeth. "Abject Bodies." Abjection, Melancholia, and Love: The Work of Julia Kristeva, edited by John Fletcher, Routledge, 1990.

Gordon, Edmund. The Invention of Angela Carter: A Biography. Oxford UP, 2017.

Haase, Donald. The Greenwood Encyclopedia of Folktales and Fairy Tales. Greenwood, 2008.

Heidari, Ali. "تحليل قصأ بر ادر عاقل و بر ادر ديو انه از منظر اسطور فديوسكوريك (دوقلو هاى مقد)" (An Analysis of the Story of Wise Brother and Insane Brother from the Perspective of the Myth of Sacred Twins). Journal of Children's Literature's Studies (Shiraz University), vol. 6, no.2, 2015, pp. 27-46.

Jordan, Michael. Dictionary of Gods and Goddesses. Facts on File, Inc., 2004.

Koshi, Anne Susan. Feminism and Fairy Tales: A Comparative Study of the Short Stories of Angela Carter, Margaret Atwood, and Suniti Namjoshi. Mahatma Gandhi University, 2003. 
Kristeva, Julia. Desire in Language: A Semiotic Approach to Literature and Art. Translated by Thomas Gora, Colombia UP, 1980.

---. Powers of Horror: An Essay on Abjection. Translated by Leon S. Roudiez, Colombia UP, 1982.

---. Revolution in Poetic Language. Columbia UP, 1984.

Leine, Antra. "Angela Carter's Version of The Little Red Riding Hood." Journal of Comparative Studies/ Komparatovistikas Almanahs, no. 6, 2014, pp. 55-64.

Mozaffari, Nahid and Ahmad Karimi-Hakkak, editors. Strange Times My Dear: The PEN Anthology of Contemporary Iranian Literature. Arcade Publishing, 2005.

Mirabedini, Hasan. "Alizadeh, Ghazaleh," Encyclopedia Iranica, 2009, http://www.iranicaonline.org/articles/alizadeh-ghazaleh-writer. Accessed 16 October 2017.

Mulvey, Laura. "Visual Pleasure and Narrative Cinema." Screen, no. 16,1975, p. 14.

Nelson, Gertrude Mueller. Here All Dwell Free: Stories to Heal the Wounded Feminine. Doubleday, 1991.

Niyazkar, Farah. "Ideal Woman, Enchanting Woman in the Works of Simin Daneshvar, Shahrnush Parsipur, Ghazaleh Alizadeh, Moniru Ravanipor, and Bilqis Solimani." Journal of Persian Language and Literature, vol. 9, no.34,2013, pp. 321-358.

Pires, Maria José. Dealing with Appetites: Angela Carter's Fictions. University of Lisbon, 2012.

Rank, Otto. Double: A Psychoanalytic Study. Translated by Harry Tucker Jr, The U of North Carolina P, 1971.

---. "The Double as the Immortal Self." Beyond Psychology, Haddon Craftsmen Inc., 1941, pp. 62-101

Sattari, Jalal. "The Pain of Immortality." Kelk Journal, no. 37,1990, pp. 138-152.

Sheets, Robin Ann. "Pornography, Fairy Tales, and Feminism: Angela Carter's The Bloody Chamber." Journal of the History of Sexuality, vol. 1, no.4, April 1991, pp. 633-657.

Smith, Kevin Paul. The Postmodern Fairy Tale: Folkloric Intertexts in Contemporary Fiction. Palgrave Macmillan, 2007.

Summers, Montague. The Werewolf. Kegan Paul, Trench, Trubner\& Co., 1933.

Talattof, Kamran. Modernity, Sexuality, and Ideology in Iran: The Life and Legacy of a Popular Female Artist. Syracuse UP, 2011.

Vatanpour, Azadeh and Katayoun Namiranian. "ريختشناسى و تحليلاسطور فُقصأعاميانٔدختر و درختكنار" (Morphology and Mythological Analysis of the Girl and Konaar Tree). Iranian Journal of Anthropology Research (University of Tehran), vol. 2, no.1,2012, pp. 169-187.

Walter, Natahsa. "Margaret Thatcher: a feminist icon?" The Guardian, January 2012.

Watz, Anna. Angela Carter and Surrealism: "A Feminist Libertarian Aesthetic." Routledge, 2016.

Wrobel, Iwona, "Femininity and Masculinity as the Axis Magical Worlds: A Comparative Analysis of Angela Carter's and Olga Tokarczuk's Heroines." Zeszyt, no.60, 2009, pp. 182-190.

Zare Kohan, Masoumeh, and Azar Daneshgar. "An Analysis of Motifs in Ghazaleh Alizadeh's Short Stories." Persian Literature Journal (Baharestan Sokhan) vol. 14, no. 35, 2017, pp. 49-68.

Zipes, Jack. Fairy Tale as Myth/Myth as Fairy Tale.The UP of Kentucky, 1994.

\section{Authors profiles:}

Narges Montakhabi Bakhtvar is the assistant professor of English Literature at the Department of English Language and Literature, Faculty of Foreign Languages, Central Tehran Branch, Islamic Azad University, Tehran, Iran. Her research and teaching scope covers contemporary American fiction and poetry, comparative literature, and modern critical thought. Her PhD dissertation was on Richard Foreman's theater studied from the perspective of Giorgio Agamben's political thought. Since then she has been surveying politics of literature within the frame of postmodern writing. Her selected publications include: "Language, Ethics, and Identity in Postmodern Theater" (2016), "Body Without Means (Gesture) in Richard Foreman's Theater" (2016), and "The Deleuzoguattarian Schizoanalysis of Samuel Beckett's 'Whoroscope"' (2011), and "A Comparative Study of Postmodern Persian and American Poetry" (2019). Her essays in press are: "Phenomenology of History and Body-Subject in Charles Olson's Poetics," and "The Common and Postmodern Identity: A Sociological Study of 'Open Theater' in America." Email: <nargesmontakhab@gmail.com>.

Hoda Niknezhad-Ferdos is a PhD candidate of English Language and Literature at the Department of English Language and Literature, Faculty of Foreign Languages, Central Tehran Branch, Islamic Azad University, Tehran, Iran. Her major areas of interest include Lacanian psychoanalysis, cognitive sciences, post-phenomenological approach, Foucauldian discourse analysis, and contemporary short story. Working as a journalist from 2003 to 2005 , she has published short stories, articles and satires in newspapers and weekly magazines such as Sib. Being interested in the issues of subjectivity and identity, she has given a speech as a book critic at Cultural Center of Book City in Tehran, Iran 2018. Her publications include: "Automaton and Tyche in Postmodern British Novel: A Critical Treatment of Chance in Jeanette Winterson's The Passion" and "Panopticism, Power-Knowledge and Subjectivation in About Khosravi's The Books of Scribes." Email: <hoda_niknejadferdos@yahoo.com>. 